\title{
"Tá cuid de na mná blasta/Some Women Are Sweet Talkers": Representations of Women in Seán Ó hEochaidh's Field Diaries for the Irish Folklore Commission
}

\author{
Lillis Ó Laoire \\ NUI Galway, Ireland
}

Copyright (c) 2017 by Lillis Ó Laoire. This text may be archived and redistributed both in electronic form and in hard copy, provided that the author and journal are properly cited and no fee is charged for access.

\begin{abstract}
This article discusses representations of women in diaries written by Seán Ó hEochaidh as part of his work as a field collector for the Irish Folklore Commission (19351971). Focusing on a number of well-described events and characters, the article reveals the collector's attitude to women as they emerge from his writing. It also shows how women could help or hinder his collecting work. The disparities of the lives of a number of working women from Donegal during the period are also highlighted.
\end{abstract}

Key Words. Storytelling, Irish Folklore Commission, Working Women, Collector, Seán Ó hEochaidh.

Resumen. En este artículo se estudia cómo se han representado las mujeres en los diarios escritos por Seán Ó hEochaidh como parte de su trabajo como recopilador de material para la Comisión del Folclore Irlandés (1935-1971). El artículo se centra en un variado número de eventos y de personajes, mostrando la actitud hacia las mujeres por parte del recopilador en sus escritos. También se indica cómo las mujeres podían influir positiva o negativamente en su labor de recogida de datos. Las desigualdades en las vidas de una serie de mujeres trabajadoras de Donegal durante el periodo en cuestión también seran objeto de análisis.

Palabras clave. Contar historias, Comisión del Folclore Irlandés, mujeres trabajadoras, recopilador, Seán Ó hEochaidh.

Interest in women in folklore has increased greatly since Angela Partridge's Caoineadh na dTri Muire (1982) heralded the first major research work on a gendered topic in Irish folklore studies. The Banshee by P. Lysaght (1986) soon followed. Although not specific studies of 
gender, these works certainly focused attention on the folklore of women. Joan N. Radner's work concerning conflicting tellings of a folktale by Peig Sayers and her son, Maidhc (Radner, "The Woman"), and later on, about coding in women's folklore (Radner, Feminist) has been influential, as has Anne O'Connor's work on dead child traditions and on the folklore of blessed and damned women in the Petticoat Loose cycle of stories (Child; The Blessed). Eilís Ní Dhuibhne's insightful commentary on representations of women in folklore ("The Old"; "International") notes the existence of "a clash between masculine and feminine traditions" ("International" 1214), one I will amplify in this paper. Indeed, Volume IV of The Field Day Anthology, where Ní Dhuibhne highlighted the conflict was a response to the exclusion of women from the original three volumes. Volume IV contains a rich variety of texts from women storytellers and singers together with supporting critical essays to contextualise and justify the choices made.

Other recent work continues to highlight the inequality experienced by women with regard to their contribution to Irish folklore studies. Patricia Coughlan's feminist readings of Peig Sayers' autobiographical texts show new ways of interpreting that important body of writing ("An Léiriú"; "Rereading"). Michael Briody outlines the male dominated dimension of public life in the founding years of the Irish Folklore Commission (The Irish) and both Diarmuid Ó Giolláin (Locating; An Dúchas) and Stiofán Ó Cadhla ("Dochtúirí") have pointed out the difficulty in giving women's lore its proper due, because of male-centred bias both within and outside the academy.

Looking at the anthropology produced by Arensberg and Kimball for 1930s Co. Clare, women clearly emerge as valued but secondary members of the society, with few of the privileges or rights of men (Family). Perspectives from anthropology from figures such as Sherry Ortner ("Is Female") whose work sees the female almost universally identified with "nature", and Edwin Ardener ("Belief") are useful. For Ardener women comprised a "muted group", a useful idea reminiscent of Gramsci's and Spivak's "subaltern" (Gramsci; Louai). In recent years, however, this muting has receded, with the realisation that the inclusion of "gender" as an analytical category in folklore studies has many opportunities for rejuvenating the old field, as the studies I have already mentioned show. Other studies such as that of Angela Bourke on fairylore ("The Virtual") and especially her magisterial treatment of the tragic story of Bridget Cleary (The Burning), and Gearóid Ó Crualaoich's groundbreaking study, The Book of The Cailleach show clearly what potential exists for the study of lore about, by and to some extent for women. Additional research also pays increased attention to the matter of gender, including a significant discussion of masculinity in the singing of Joe Heaney (Williams and Ó Laoire). Coughlan's robust feminist critique ("An Léiriú"; "Rereading") is particularly helpful in destabilising a dominant masculinist gaze that seems to have led to Peig's enduring negative image among those who read her as part of their prescribed course in secondary school. Although, of course, Peig was never a compulsory text, and although it is almost twenty years since Peig was on the curriculum, the stereotypical version of Peig still carries powerful resonances. In a careful and nuanced reading of the folktale "The Woman With No Hands", Stiofán Ó Cadhla (176-198) explores the tensions he identifies in a story told by a woman of very little formal education to two men, at the time a priest and afterwards a bishop, and a doctor, belonging to a wealthier, professional echelon of society. That essay is among the best in his very readable and indispensable book, An tSlat Feithleoige, an approach that I am much indebted to in a paper I wrote about Bab Feiritéar's storytelling (Ó Laoire, "Humor") using Bo Almqvist's and Roibeard Ó Cathasaigh's excellent collection of her stories as a primary source (Ó Bhéal).

After I had read Ó Cadhla's essay, similar questions occurred to me regarding a particular story recorded by the renowned Anna Nic a' Luain for Caoimhín Ó Danachair and Seán Ó hEochaidh for the Irish Folklore Commission's sound recording project in 1949 (Ní 
Dhíoraí; Lysaght, "Visual" 98-114). On that occasion, one of the stories Anna chose to tell was that of a lazy young woman who got married and who possessed none of the skills expected of a married woman (ATU501) (Ellis Davidson 107; Uther). She was unable to work wool or do any kind of related work that women generally carried out in order to contribute economically to the family's maintenance. Anna's story seems particularly escapist in tone, allowing the three grotesque supernatural helpers to get the lazy, unskilled young woman out of her difficulties by deftly completing her required tasks. Her husband, the prince, is so shocked by the deformities suffered by the old women that he forbids his wife to do any menial work in future, so that she is able to enjoy a life of unqualified ease with her consort afterwards. The choice to tell such a story on the occasion of making a sound recording is interesting and begs questions similar to those posed and answered by Ó Cadhla. Was this a choice or a request from the collector? If a deliberate choice, did the storyteller intend to imply that her own life, full of the same kind of incessant labour necessary to eke out an existence was not a desirable one and that she entertained fantasies of escape? Did she wish to convey that she would also have liked access to the kind of ease the heroine in her story enjoyed? And additionally, did she wish to suggest to those who were recording her lore that they had a fine carefree existence, being paid for the work they were doing in recording the oral heritage of Donegal, and, in Ó Danachair's case, of other parts of Ireland? Ó hEochaidh had recorded the tale the previous year in 1948 (NFC 1033, 201-6; Ó Seachnasaigh 244-7), so that two versions of the narrative are extant. For the moment, I will leave these questions aside, but raising them suggests that they could provide insight into the relationships between collectors and narrators. The fact that Ó Seachnasaigh notes Anna Nic a' Luain's empathy for an abused female character in another of her tales suggests that such an enquiry would be productive, especially in relation to Seán Ó hEochaidh, the field worker who worked most extensively with her (Ó Seachnasaigh 285-298). Ó hEochaidh was appointed as collector for the Irish Folklore Commission in July 1935 and served the Irish Folklore Commission and its successor, the Department of Irish Folklore, for fifty years until 1985. He was one of the Folklore Commission's most prolific collectors and conducted his work mainly in Donegal (Ainm.ie). It was he also who ensured that Anna's renown as a storyteller and bearer of all kinds of tradition was spread far beyond the remote valley where she lived out her life (Ó Laoire, "The Gaelic").

In this paper, I intend to give partial answers to questions about Seán Ó hEochaidh's engagement with women as he met them in his capacity as a full time folklore collector. A palpable tension pervades Ó hEochaidh's field diaries concerning his relationships with women. Although he collected very successfully from individual women, it seems that women as a group could be a cause of some stress for him. For this purpose, I confine my study to the eight volumes of field diaries he compiled as part of his ordinary service for the Commission, a labour that ensures we have a comprehensive record of many of his field encounters with storytellers, singers and others who related greater or lesser amounts of oral tradition to him. I have not included a large amount of other material in the form of letters and other correspondence in the UCD archive for the purposes of this paper. I narrow my scope still further in an effort to curtail the large corpus of material to a particular focus, one that may seem unusual. I do not attend here so much to storytellers or singers, although inevitably - they are dealt with to some extent, but to supporting women, if I may use the term. By this I mean women who facilitated the smooth progress of his collecting, the wives of storytellers, for example, or those who acted as landladies and providers of hospitality in Ó hEochaidh's lodgings. Though seemingly peripheral to the project of folklore collection, such women wielded considerable power and influence over the collector's circumstances, by turns helping or hindering his work in significant ways. 
Using this approach, it is possible to gain a considerable understanding of Ó hEochaidh's views on women and their position in Irish rural society from 1935 to 1950 . Over ninety individual persons of female gender, including some children, appear in the diaries (Mac Aoidh). This number comprises the important female narrators and singers as well as those who are mentioned briefly once, never to appear again. Because of the large catalogue of individuals involved, reducing it to a small core helps us to answer important questions about the representation of some women in his field accounts. Inevitably, even with this narrower view, however, the choice of material is solely mine, based mainly on the questions I raise in this paper and dealing with particular incidents that I believe to be particularly striking. Taking the spotlight off the narrators also helps to reveal how the work of gathering folklore fitted in with the lives of those who were not always directly connected in the collector/informant dyad, revealing other interesting and important details.

Studying females in Ó hEochaidh's diaries provides a way to see how the male gaze perceived women. Ó hEochaidh was a man of his time. He had had a thorough, if limited, education from his uncle Pádraig Mac Seáin (1895-1981). He had neither attended secondary school nor university, nor had he migrated away from his native Donegal, as many of his generation were forced to do, his own four younger siblings included. Ó hEochaidh's "university" comprised the five seasons he spent working as a salmon fisherman with his Teileann (Teelin) neighbours, experiences to which he later credited his success as a folklore collector. Ó hEochaidh, then, can be regarded as quite a conservative male, with fairly conventional expectations of women's roles. Although this may be the case, he emerges as an equanimous and level-headed individual, who treats the women he meets with respect and courtesy. There are however some notable, and sometimes hilarious, exceptions to this rule where he is critical and even hostile to certain women. Negative commentary seems to be directed at women such as storytellers' wives who could not be relied upon to be positively disposed to his activity as a collector. Such negative attitudes added additional challenges to Ó hEochaidh's already difficult job. His antagonistic attitude to such individuals does not spring from a general misogyny, in my view, although it may be so expressed. From this perspective, the unsympathetic attitude of some women to his attempts to collect from their male relatives can be regarded primarily as a professional concern, although expressed in quite traditionally stereotypical anti-woman terms. Those who treat him well, likewise, are also praised according to traditionally approved and sanctioned virtues attributed to women. Ó hEochaidh was, like us all, produced by a particular habitus, a world view that emerges clearly from his diaries. The point is, therefore, not to criticize his attitudes from the hindsight of a later more liberated era, but to try and understand the work he did, and how he did it, by concentrating on this important element. In doing so, I am reducing the number of women from ninety to six individuals who stand out in various ways in their capacities as hostesses or housekeepers. Despite its limitations this necessary reduction allows space to discuss directly some important questions.

I begin then, with an encounter that occurred in Gleann Cholm Cille (Glencolmcille) Donegal, in March of 1936, before Ó hEochaidh had completed his first year as a full-time collector. The episode reveals the liminal and downright dangerous nature of being a folklore collector and Ó hEochaidh's dependence on good will to achieve his aims. It also dramatically shows how women, in facilitating storytelling, were central to achieving success in recording it. In the following excerpt, concerning the events of the $13^{\text {th }}$ March (NFC 421, 137-141), Ó hEochaidh describes how he struck the narrative gold and made friends with an elderly storyteller and his wife. ${ }^{1}$ Initially, everything goes smoothly, but events soon take an unexpected turn. We begin here with a general statement about the inquisitive nature of women as he relates his successful attempt to curry favour with the old lady of the house: 
Dálta na mban uilig ba ghairid a bhí mé istigh gur chuir an tseanbhean seo tuairisc cé mé féin agus caidé'n seort gléas a bhí liom. D’inis mé féin di chomh maith agus a tháinig liom agus ba ghairid go raibh sí carthanach i gceart liom. Rinneadh braon tae ansin agus lena sásamh, ar ndóigh, b'éigean domh braon de seo a ól. Chaith Padaí smailc den phíopa i ndiaidh an tae, agus ansin chuaigh muid i gcionn na hoibre.

Chuir mé isteach eiteán dó ar an mheaisín, agus nuair a mhínigh mé dó caidé a bhí aige le déanamh chuaigh sé i gcionn scéil. Agus ba mhaith uaidh scéal a inse, ach go labhraíonn sé an-tiubh. Nuair a bhí an chéad scéal insithe aige tháinig girseach bheag leis féin agus chuir sé í seo ar siúl go Coillte Feannaid fá choinne fear a nighne, a bhfuil mórán scéalta aige. Ba ghairid a bhí sí ar siúl go dtáinig sí agus an fear seo Pádraig Ó Baoighill - léi. D'fhág Padaí Bhriain inse na scéalta ansin agus thug sé áit don fhear eile. Bhuail an fear seo a dh'inse ansin agus nuair a bhí an tríu scéal insithe aige sciob a bhean thart leis an fhuinneoig. Tháinig sí seo isteach agus is é an chead bheannú a thug sí domh "drochrath" a chur orm agus ar a fear ag inse an scéil. Thug sí an darna hiarraidh ar an mhaide briste agus shíl mé go ndeánfadh sí stifirlín díom sula bhfaighinn faill m'anam a thabhairt do Dhia nó do Mhuire. Mar sin féin bhain a hathair fúithi rud beag agus cuireadh ciall inti; ach b'éigean don fhear imeacht agus scéal leathchríochnaithe aige.

Ba é an rud a ba chiontaí le seo cuireadh mac di mí roimhe seo agus shíl sí gur ag déanamh pléisiúir a bhí a fear nuair a bhí sé ag caint isteach san Ediphone. Ní raibh sí sách i gcéill i gcás ar bith. Sílim gurb é sin an iarraidh mharfa ba mhó a fuair mé riamh. D'imigh sí féin agus a fear abhaile ansin agus nuair a shíothlaigh an uile sheort síos chuaigh Padaí é fhéin i gcionn na scéalta arís. D'inis é leis ansin go dtí i dtrátha an deich a chlog agus shíl sé go raibh deireadh insithe aige ansin.

\section{Translation:}

Like all women, I was not long inside when the old lady inquired who I was and what kind of a contraption I had with me. I told her as well as I could and soon she was very friendly with me. A sup of tea was made then and to please her, of course, I had to drink a drop of it. Padaí had a puff of his pipe after the tea, and then we began the work.

I inserted a cylinder for him on the machine, and when I explained to him what he had to do, he began a story. And he was good at it, except that [138] he speaks very quickly. When he had completed the first story a little girl belonging to himself entered and he sent her off to Coillte Feannaid to get his daughter's husband, who has many stories. She soon returned with this man - Pádraig Ó Baoighill. Padaí Bhriain left the storytelling to this man after that. This man began storytelling then and when he had told his third story his wife darted past the window. This one came in and the first greeting she gave me was to wish "bad cess" upon me and on the man who was storytelling. She made her second attack at the tongs and I thought she would make a dead man of me before I had time to ask God or Mary for mercy. Her father succeeded in calming her somewhat, all the same. But her husband had to leave with his story half-told.

The problem was that their son had died the previous month and she was convinced that her husband had been having fun when he was speaking into the ediphone. She wasn't sufficiently stable anyway. I think that was the worst death attempt I ever received. She and her husband went home at any rate and when all the fuss died down, the father began to tell stories again. He continued to tell until ten o' clock and he thought he had told them all by then. (Translation mine) ${ }^{2}$ 
This short account tells us a lot about Ó hEochaidh's own practice and experience as a field collector as well as about attitudes to women. His liminal position is clear, especially so because he is describing a first visit. He reaches the storyteller's house, in an isolated location, at the end of a mile-long loaning, or track, which had to be walked, carrying the heavy $20-\mathrm{kg}$ ediphone. This, after an already arduous car journey on another narrow track barely suitable for motor transport had already proved a considerable ordeal. Difficulties of transport comprise a recurring motif in Ó hEochaidh's diaries, one found in similar accounts by other male folklorists (Kodish 576). The storyteller's wife was blind but he managed to ease any reluctance and accepted her hospitality by drinking the tea prepared for him. This was a necessary part of the ritual of becoming acquainted though it was the least of his concerns. His characterization of "all women" as inquisitive invokes stereotypical male-centred cultural norms. Just when things seemed to be going along well, and he had managed to locate a second, younger storyteller, all of his painstaking work is undone by a bereaved woman, angry at her husband because he was, in her view, enjoying himself during the strict mourning period following the recent loss of their son. Ó hEochaidh's professional disappointment at the loss of half a story emerges clearly as being at least as important as his concern for his own safety. Three persons of female gender appear in this account, the old wife of the storyteller and a young daughter of his, pressed into service as a messenger to get his son-inlaw to come and tell stories for the collector. The description of the elder sister's furious intervention focuses the narrative, providing a dramatic climax. Despite the disruption, however, the episode does not completely ruin Ó hEochaidh's collecting, as the man whom he had originally come to record continued to tell stories until the hired car Ó hEochaidh had used to get to the house arrived to pick him up again at 10.30 p.m. or so. The idea that storytelling was a serious business, more than entertainment, underpins the passage, as does a suggestion that the angry woman could not comprehend the serious element introduced by a collector's presence that transformed the activity from "play" into "work".

The majority of women welcomed Ó hEochaidh warmly and effusively and received praise for it. In one early example from Kilcar, just over a week after this episode, Seán was treated to a full high tea, served with enough food to feed a boat crew, in the seomra or the parlour by the woman of the house where he recorded the storyteller Pádraig MacUibhir (Patrick McGuire). This house was not the storyteller's home, but another house named by him as a good rendezvous. Interestingly, this house is named as belonging to the woman, Anna Ní Eigheartaigh, An Dúinín (Doonin), part of the townland of Doire Leathan, (Derrylahan) although her husband was present. ${ }^{3}$ When Ó hEochaidh remarks rather shamefacedly to the storyteller during the meal that this generosity is excessive, the answer he receives is telling (21 March 1936; NFC 421, 173-4):

dúirt sé liom gan íontas ar bith a dheánamh de sin, nach rabh a'n lá ó rinne slat cóta dó nach raibh sé ag éisteacht lena bhunadh á rá go raibh an teach seo gortha fána mhaitheas fá bhia.

he told me not to pay any heed to that, that there hadn't been a day since he was a small child that he had not heard his people saying that this house was famous for its generosity regarding food.

Again, this episode holds interest because of the way the storyteller chose a different location for the meeting, away from his own house, knowing that the occupants of the chosen venue would be well disposed to Seán's collecting project, and that things would go well there. 
Another element that characterizes his description of the storytelling event is the extreme interest all the participants took in the proceedings. Ó hEochaidh remarks the storyteller's keenness to begin narrating and, furthermore, the hostess's brother's tears at hearing certain stories that had not been performed in a long time, reminding him of deceased individuals who had told them. Even the hostess herself reacted as she busied herself with her tasks. Ó hEochaidh mentions several instances of how she stopped and stared into space as if she had received some bad news. But it was her own interest in hearing the stories and her absorption in them that caused these strange-seeming pauses. In this description, it is obvious that men had leisure to narrate, or listen, while a woman continued to work and, if she did enjoy listening to stories, she was still always occupied with some other task as well. Managing the folklorist's visit falls to the woman as hostess, to be smoothly accommodated with other jobs (Kodish 576) though it was not a mundane event but a special occasion which the woman was happy to organize. The idea that "a woman's work was never done" is borne out clearly.

Ó hEochaidh subsequently expanded out of his own area to the north, going to the district around An Dúchoraidh (Doochary) (NFC 584, 15-92) as a first port of call after Gleann Cholm Cille and Ard a' Ratha (Ardara). In his opening paragraphs, he seems quite dejected and not very hopeful about his prospects, claiming that folklore is marbh - "dead" (NFC 584, 18) in this neighbourhood. This, despite the fact that his landlady, Eibhlín Ní Ludhóg blesses him with holy water and implores God to favour him, while her sister Maighread casts an old shoe out the door after him for luck as he leaves the house on his first day, after he has identified a potential source. The task of locating storytellers in a new area was a daunting one, because he had no real confidant or guide. By following a man driving a few sheep along the road, however, on the hunch that he had the look of a storyteller about him, he strikes up a conversation. He learns that this man, Seán MacCormaic, is himself a storyteller. Seán and his father, Conall, of Doire Leac Conaill (Derryleconnell), soon number among the collector's most stalwart informants, from whom he was to record extensively.

A recurring first arrival scene of entering the house and surveying its occupants and their demeanour ensues, in a brilliantly descriptive piece. Mrs. Bridget McCormack, the storyteller's wife, is my centre of attention, because of a few revealing anecdotes about her. When Ó hEochaidh first came in, Mrs. McCormack was not visible at all. In fact, Ó hEochaidh was not even certain that anyone else was there. He arrives at dusk on $5^{\text {th }}$ October 1937, as the light is failing, probably about 7.00 p.m. He can barely recognize the outline of the storyteller, who is making porridge by the fireside as he approaches. An air of tentative apprehension pervades this passage. The fact that the preparation of evening supper, usually a woman's task, is being performed by a man is striking. Ó hEochaidh guesses there may be a human form visible in the settle bed but he cannot be sure, the light being so poor. Eventually the old man, Conall, satisfied that the porridge is cooked, lights a lamp and almost miraculously reveals both his face and the rest of the house's interior. Ó hEochaidh concludes that he is correct in surmising that there is a human form in the bed. This turns out to be Conall's wife and it transpires that she has been bedridden for twenty-four years. She is, also, as Ó hEochaidh learns from her son Seán, chomh bodhar leis na clocha, "stone deaf" (NFC 584: 30-31). When Conall begins reciting his narrative into the ediphone, Ó hEochaidh notices the bed clothes stirring and the wife sits up in the bed calling her husband by name. He ignores her, but on the third call, he becomes distracted and replies in a loud, gruff tone for her to be quiet. Of course, being deaf, she does not hear him. Eventually, she calls out, and I quote (6 October 1937; NFC 584, 31/32):

"A Chonaill, a amadáin bhoicht, tá tú a séideadh isteach ins a' ghléas sin anois," a deir sí, "agus beidh tú comh hataithe amárach agus nach bhfaigheann tú amach ar an doras. Ach 'á mbéadh fód mónadh agamsa chnagfainn thú!" 
"Conall, you poor fool, you're blowing into that contraption now," she says, and you'll be so swelled up tomorrow that you won't get out the door. But if I had a clod of turf, I'd thump you!"

Once more their son tells Seán not to be concerned that she is ar chéill na bpáistí - "in her second childhood" - a way of saying that she had dementia. Recording proceeds despite the old lady's protests and OO hEochaidh pronounces himself very happy with the nights of storytelling provided by these two men, father and son, considering himself fortunate in meeting Seán and Conall MacCormaic who were both active storytellers and keen to tell him. As with many other such accounts in his field diaries, his account is related with a welldeveloped sense of the scene's comic potential. As someone steeped in the storytelling tradition himself, his intuitive recourse to traditional storytelling techniques is not surprising. Some of the remarks, however, reveal Ó hEochaidh's prejudice that women as a group can be a risk to his work, when they were not well disposed to him (NFC 584, 52-3):

B'éigean domh a dhul 'na leapa ionnsair an tseanbhean go bhfuair sise greim láimhe orm fosta. Bhí an tseanbhean ag éirí níos carthanaí 'ach uile oíche, agus bhí anlúcháir orm fá seo nó níl dream ar bith is mó a chuireas fearg orm nó mná a mbíonn drochthiúin orthu - agus leóga is annamh a bíos sé maith ar chuid acu.

I had to go to the bedside to the old woman so that she could take my hand as well. The old lady was growing friendlier as each evening passed, and I was very pleased about this because there is no group that angers me more than bad-tempered women, and, indeed, it is rare to find some of them in good humour.

Ó hEochaidh's instincts as a collector are foremost when making these remarks, probably affected by the experience in Gleann Cholm Cille, discussed above, and by other episodes in which the presence of women delayed or prevented his progress. His comments show his belief that his work could be jeopardized by the unwillingness of women to support him, even though they are not the storytellers. Clearly, the previous incident involving the young woman who had lost a son remained impressed on his mind. Certainly it is unique in the diaries. The fact that it happened early in his career, however, made a lasting impact. The bereaved mother's outburst recalls the geilt, or the portrayals of keening women as reported from eyewitness accounts and from the texts of laments themselves (Partridge "Wild Men"; Caoineadh; "More"; "Performing"). The behaviour shows the persistence of older modes of behaviour, where grief was extravagantly displayed, rather than borne decorously and quietly. Ó hEochaidh's upbringing had exposed him, through his uncle Pádraig Mac Seáin's influence and that of others, to values that Lawrence Taylor identifies as "civil Victorian Catholicism" (98-100). These ideals represented a move away from more "ethnically" ambiguous indigenous ways of being, toward those more acceptable both to the Catholic church and to "respectable" society, accelerating after the Famine (Bourke The Burning; Carbery; O'Sullivan). The abandonment of such modes of behaviour was tied to upward social mobility and adherence to them represented what amounted to a class division. Those who retained these older ways belonged to a poorer, less educated group, excluded from current discourses of advancement and progress. The description of remoteness and poor road access to the storyteller's house in Gleann Cholm Cille, provides a coded acknowledgement of this division, one that Ó hEochaidh raises in another cogent passage in the diary (NFC 1289, 5661; Ó Laoire "The Gaelic"). The woman's emotional reaction additionally confirms that these 
people belonged to a different social class from the collector and that tensions inherent in those differentiations persisted.

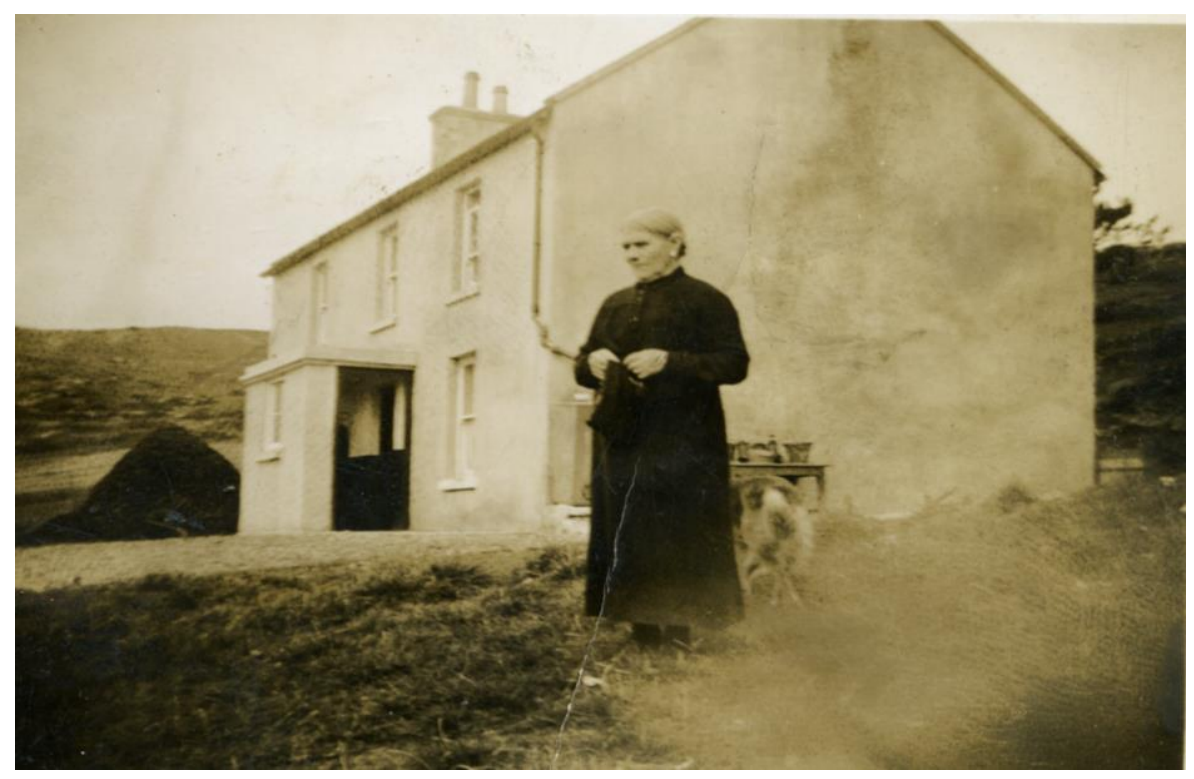

Figure 1. Sábha Bean Mhic Eiteagáin (Mrs. Sofia McGettigan) outside her house in Cnoc na Muirleog (Crocknamurleog), Downings Co. Donegal, 1940. Photograph: Seán Ó hEochaidh? Used by kind permission of the National Folklore Collection, Dublin.

Seán's descriptions of his landlady in Cnoc na Muirleog (Crocknamurleog) in Downings, Sábha bean Mhic Eiteagáin, or Mrs. Sofia McGettigan, present this class division from another perspective. In the photograph (Figure 1), we see Mrs. McGettigan standing in front of the house she ran. Indeed, the dwelling dominates the picture and the connection between the house and its mistress is clear. The two storey, slate-roofed, building emanates prosperity and propriety. Seán Ó hEochaidh began collecting in Na Dúnaibh (Downings) and Fánaid (Fanad) in January 1940. When moving to a new area, he would ask his hosts about people who might have stories for him and frequently, he found that some of them were storytellers themselves. Certainly, even if they were not, they gave him as much help as they could. Mrs. McGettigan, however, his landlady in Downings, seemed intially to have no real knowledge of the kind Ó hEochaidh wanted, although he said she had heard something about all the matters that he mentioned, he could not press her on the topic. He expresses surprise that she does not know more, expecting that, because she is an older lady, she ought to have answers to his questions (April 1940; NFC 727, 140-141). She is, however, able to give him good accounts of making clothes - and he confirms that when he is dealing with the appropriate topic (ag gabháil don ábhar cheart), in this case, a gender specific topic, he is able to make good progress.

On May Day, he asks her about superstitions pertaining to that day, one of the Quarter Days with extensive lore well-known at that time to many people (Danaher). Again, however, he is disappointed not to get good answers to his questions and wonders why a woman of Mrs. McGettigan's advanced age does not know more. Although she has heard of these matters, she does not have a large store of knowledge to bestow on him. This changes later on in the year, however, at the summer solstice, Oíche Fhéil Eoin, or St. John's Eve (23 June), as it is known in Donegal. This observation of the feast remained very much alive in Downings 
in 1940 as Ó hEochaidh's account of the $23^{\text {rd }}$ June 1940 amply demonstrates (NFC 727, 392 394):

Tráthnóna thug mé fá dear tine ar achan chnoc agus ardán ins an cheantar. Níor smaoitigh mé ar feadh tamaill caidé ba chiall dó na tinte seo, ach i ndiaidh tamaill smaoitigh mé gurbh í Oích' Fhéil Eoin a bhí ann agus sin an rud a d'fhág an ceantar seo go huile lasta suas. Anonn tamall i ndiaidh dul ó sholas dó dúirt bean an tí - bean Mhic Eiteagáin - go raibh an t-am againn féin cúpla aibhleog a chur amach. Thug sí léi bucóid agus líon sí suas lán aibhleoga í agus chuaigh sí amach léi fhad leis an chlaí bheag a bhí os coinne an tí. Fuair sí bucóid mhór mhónadh ansin, agus nuair a bhí sí réidh bhí craos tineadh aici. Thug sí léi a coróin Mhuire ansin agus chuaigh sí féin amach agus síos ar a dhá glúin [sic] ag taobh na tine. Tá mé cinnte gur chaith sí bunús uaire an chloig ag urnaí agus nuair a bhí sí réidh thug sí léi an maide briste agus níor fhág sí a'n chuibhreann préataí nó coirce fán teach nár chaith sí ceann de na haibhleoga isteach ann lena shábháil ar mhilleadh na bliana. Ní raibh duine ar bith thart ins an pháróiste nach dtearn an rud céanna amach ó na hAlbanaigh. Dúirt bean a' tí liom gur chuimhneach léi an t-am ar ghnách leis na hAlbanaigh ins an cheantar a theacht agus giota dh'aibhleog a thabhairt leo as na tinteacha a bhíodh amuigh acusan agus á gcaitheamh fríd a gcuid cuibhreann, ach sin rud nach ndéan siad anois.

In the evening, I noticed a fire on every hill and height in the area. I couldn't think for a moment what the reason was, but after a while I realised that it was St. John's Eve and that that was why the place was all ablaze. A little after dusk, the woman of the house, Mrs. McGettigan, said it was time for us to put out a few embers. She took a bucket and filled it up with embers and went out with it out to the little ditch in front of the house. She got a big bucket of turf then and when she was finished she had a roaring fire.

She got her Rosary Beads then and she went out herself and got down on her two knees beside the fire. I'm sure she spent the best part of an hour praying and when she finished, she took the tongs and she did not leave a patch of oats or potatoes that she did not throw an ember into it, to save them all from the destruction the year might bring. The landlady said there was nobody in the area that did not do this apart from the Protestants. She said she remembered when Protestants would come and take embers from their own fires and scatter them among the fields but that they didn't do that now.

This account reveals the connection between Mrs. McGettigan's deep Christian faith and her observance of folk customs. May Day was not a Christian holiday. Quite the contrary, it had overt non-Christian associations, whereas the activities attached to the feast of St. John $\left(24^{\text {th }}\right.$ June) could be legitimated as a Christian saint's feast day. The customs associated with May Day were pisreoga, superstitions, but lighting a fire to honour the Solstice festival might be accompanied by reciting the Rosary and praying for a blessing on the crops. Both calendar dates are deeply concerned with good fortune, but lie on either side of a divide that Mrs. McGettigan observed strictly. Although the solstice is also a pre-Christian calendric marker, its Christian associations allowed its power for staving off bad fortune to be invoked, while other elements of folk tradition were to be avoided. Mrs. McGettigan's clear and unambiguous choices in this regard indicate how individuals adapted folk belief to suit their $\mathrm{t}$ inclinations, convictions and interests. The account provides invaluable context for such observance, also bringing questions of sectarian differences and the changes that had occurred over time to the fore. The change appears to mark the advance of modernity and the retreat 
from folk customs. The premise that folklore was disappearing because of modernity was a central trope of the IFC's mission and Ó hEochaidh's writings clearly project that belief (Ó Giolláin, Locating). Ó hEochaidh later found a similar avoidance of superstitious lore in another of his storytellers in the Croaghs (Na Cruacha Gorma, The Bluestack Mountains). Aodh (Eoghain Mhicheáil) Mac a' Luain was also reluctant to discuss May Day, and Ó hEochaidh remarks, "tá an creideamh róláidir ann"- religion is too strong in him (NFC 1289, 104). Equally with Mrs. McGettigan, her strong faith precluded any real discussion of nonChristian aspects of traditional belief.

Mrs. McGettigan chose to foreground further aspects of traditional values in her dealings with others as a hostess, by personifying, like Anna Ní Eigheartaigh, already discussed, the central virtue of infallible hospitality. She remarked to Seán that to ask a guest whether they would take food was itself a failure of womanly hospitality, as they were sure to refuse. The correct behaviour was to prepare the food and then let the guest choose to partake or not (NFC 727, 106-7). Such behaviour indicates standards of generosity central to traditional Ireland's aristocratic gift giving mentality and how these remained important despite other accommodations to a modernizing society.

As we have seen, once he moved out of the immediate area of Teileann and Gleann Cholm Cille, Seán was obliged to stay in lodgings during his collecting trips. Landladies, therefore, feature quite often in his diaries. Each of them had a different personality and Ó hEochaidh's descriptive powers capture compelling portraits of these busy, competent women. When he stayed in Na Doirí Beaga (Derrybeg), Gaoth Dobhair (Gweedore), for example, his hosts, the Friels, of Óstán Radharc na Mara (The Seaview Hotel), were especially alert in trying to identify storytellers and others who could give him information. Similarly in Mín a' Chladaigh (Meenaclady), the eastern edge of the parish of Gaoth Dobhair, Mrs. Máire Uí Dhúgáin (Mrs. Máire Duggan) helped him to identify storytellers and singers there. She also welcomed the use of her kitchen as a location for ediphone recording, like Mrs. McGettigan, providing tea and other refreshments. He collected from at least two women in Mín a' Chladaigh, one of whom, Biodaí Sheáin, or Bríd Nic Comhaill, was blind. This woman knew many songs and prayers and had to be led by the hand to the house to recite her lore for Seán. His landlady's house was also a shop and a visiting house accustomed to regular callers. Máire Uí Dhúgáin fully supported of all his endeavours, even to the point of calling out encouragement to Bríd when she was reciting or singing her prayers for him: "Mo chroí thú a Bhiodaí, maith thú leabhra" - my heart to you Biddy, well done indeed! (NFC $727,51)$.

The same went for Mrs. Friel, mentioned above, in the Seaview Hotel, further south and west in the heart of Gaoth Dobhair, who went to the trouble of accompanying Seán on his first visit to one of the principal women storytellers of the area, Mrs. Máire Mhic Fhionnlaoich, or Máire Mhicí as she was known. He visited her regularly from early April to late July of 1938. Other collectors had visited Máire Mhicí before Seán and she had been subsequently offended to have been passed over when storytellers were being invited to the local Irish college to tell stories to the students. This had made her wary and reluctant to tell her stories. Seán must have been pleased that Mrs. Friel was with him, knowing that it would increase his chances of getting Máire Mhicí to cooperate. They both travelled together there by car. Previously, when Máire came to the shop, Mrs. Friel had tried to persuade her to tell her stories for Seán, entreaties that initially fell on deaf ears. With Mrs. Friel's help, however, Seán was able to convince Máire to tell him her stories. About this, he remarks "Tá cuid de na mná blasta!" - some of the women are sweet, i.e. well-spoken and persuasive, and adds that Mrs. Friel kept talking to Máire until she finally exacted a promise from her to tell him whatever she knew (NFC 584, 175). Máire died in 1958 at the age of 89, so in 1938, she was 
about 69 years old, and still an active woman by Seán Ó hEochaidh's account, herding her cattle daily. Seán managed to visit her very often after that and recorded most of her lore.

Máire Mhicí Mhic Fhionnlaoich and Anna Nic a' Luain are among the outstanding women informants that Seán Ó hEochaidh recorded. To these may be added, from Teileann, Máire Ní Bheirn and Máire Uí Cheallaigh, friends who enjoyed the work of recording folklore and who were very supportive of Ó hEochaidh as a relative and neighbour. Máire Ní Dhonnagáin, also of Teileann, was another star who helped him enormously (Lloyd and Magee 1947: 21-25). In Málainn Bhig (Malinbeg), there was another Máire Mhic Fhionnlaoich who knew many fairy legends (Ó Laoire, "Dialann" 109-115). Peigí Mhór Ní Ghadhra, of Clochar, Gleann Cholmcille, and the sisters Máire and Róise Nic a' Ghoill of Ard a' Rátha were outstanding singers. Bríd Nic Comhaill, the blind singer from Mín a' Chladaigh, already mentioned, features in Angela Bourke's work (1982), but it is unusual to see descriptions or discussion of the others apart from Anna Nic a' Luain. They and others provide an illuminating focus for discussion from a gender perspective that must await another opportunity.

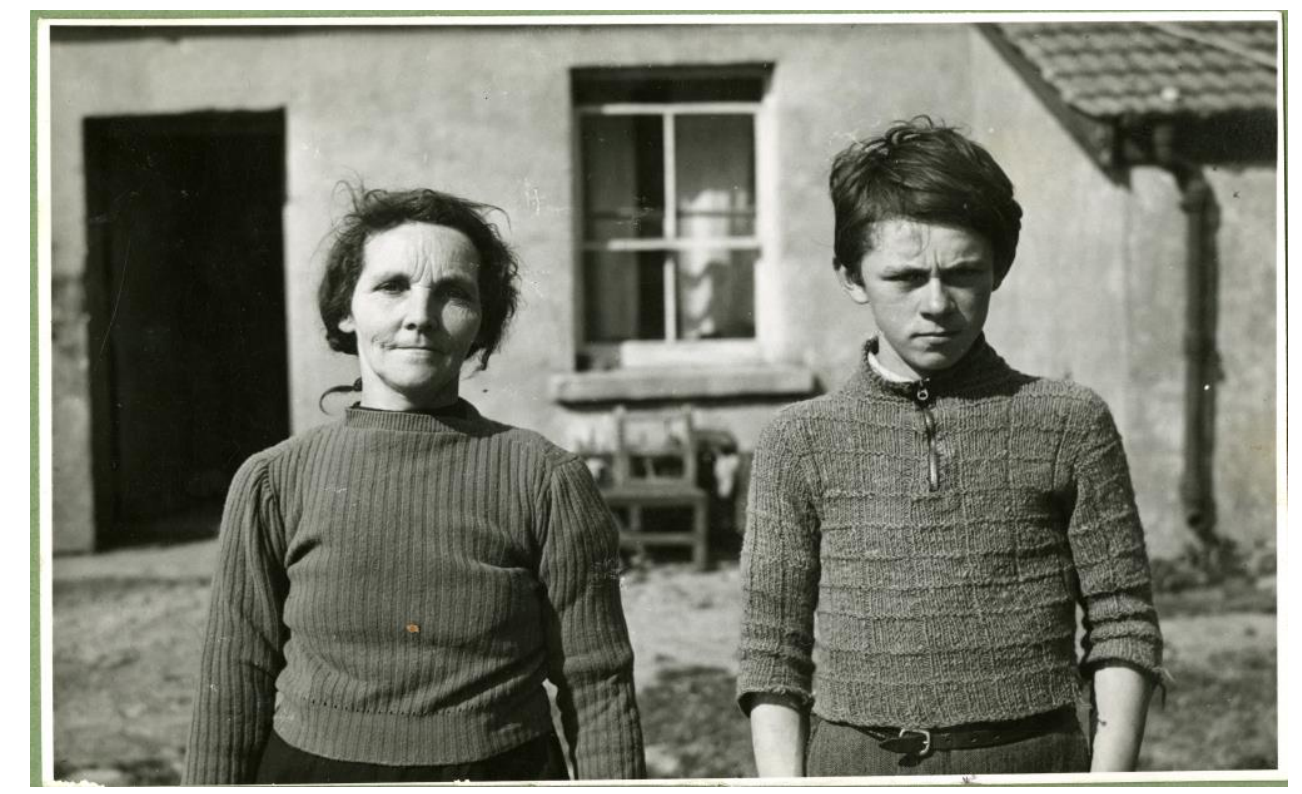

Figure 2. Cáit Mhic Giolla Dhiarmada (Catherine McDermott) and her son Seán, 1949. Photo: Seán Ó hEochaidh. Used by kind permission of the National Folklore Collection, UCD.

For now, I will finish with a vignette of another of Seán's landladies, Cáit bean Mhic Giolla Dhiarmada, Mrs. Catherine McDermott, who lived in Cruach Leac (Crolack), on the edge of $\mathrm{Na}$ Cruacha Gorma, the Bluestack mountains or the Croaghs, where Seán went first in May of 1947. Ó hEochaidh tried to get lodgings with the Mac Aoidh family, as Liam Mac Meanman (Ó Catháin) who had collected for the IFC before Seán, had stayed there. Ó hEochaidh knew, therefore, that it was a good, comfortable house. As matters transpired, however, the Mac Aoidh family had no room and he had to seek accommodation elsewhere. Mrs. McDermott agreed to keep him from Monday to Saturday, but insisted that he fend for himself on Saturday evenings and Sundays. Unable to find an alternative, Ó hEochaidh accepted. Before she appears in the field diaries, Mrs. McDermott features in the story of the RAF Short Sunderland DW110 plane that crashed in the Bluestack mountains on $31^{\text {st }}$ January 1944 , killing seven, with five injured (Donegal Times). It was to her house that the survivors made their way after they had left the wreckage. Mrs. McDermott had been recently widowed prior 
to the crash and was left to raise five children. Understandably, she was at first frightened by the arrival of these strange men. The survivors, however, never forgot her kindness to them. Knowledge of Mrs. McDermott's widowhood and the challenges of providing for her family add to our ability to understand Ó hEochaidh's experience as a paying guest in her house. He was happy enough to have found lodgings at all, and Mrs. McDermott was kind to him. He attributes her inability to keep him all week to the difficulty of getting to the shops to purchase the necessary goods (NFC 1289, 106). She helped him identify storytellers and allowed her kitchen to be used as an impromptu location for the collection of stories. It is useful to compare his experience with Mrs. McDermott to his gold standard of landladies, Mrs. O'Donnell in An Craoslach (Creeslough), with whom he had lodged in 1940 prior to his visit to Downings. This is how he described his stay there (NFC 727: 8-9):

Le tosú leis an bhean a raibh mé a stopadh aicí i dtigh ósta Uí Dhomhnaill, bhí sí ar bhean chomh maith agus ar stop fear nó bean riamh aici. Bhí sí ina ceann chomh maith domh agus dá mba í mo mháthair í. Bhí sí fá mo bhun agus fá mo bharr ó d'éireoinn ar maidin go dtéinn fá chónaí ins an oíche, agus leoga is minic a chóirigh sí na héadaigh orm i ndiaidh a dhul fá chónaí. Tá shliocht uirthi; tá a clú agus a cáil ar fud na hÉireann, agus má gheibh an bhean a choíche "na bhFlaitheas de bharr déirce nó dídean na hoíche a thabhairt don té a bhfuil sé a dhíobháil air, beidh sí ar bhean acu, go saolaí Dia í!

To begin with the woman with whom I was staying in O'Donnell's Hotel, she was among the best landladies that ever man or woman lodged with. She was as good to me as my own mother. She attended to my every need from when I would rise in the morning until I would go to bed at night, and indeed, she often tucked me in after I went to bed. She has earned the reward; she is known the length and breadth of Ireland, and if ever a woman goes to Heaven because of her charity or for sheltering someone at night who is in need of it, she will be among them, may God grant her a long life!

In contrast to that glowing report, it is certain that he found Mrs. McDermott's house neither particularly comfortable nor conducive to the work that he engaged in during the day. He rarely called to his informants before evening as they could often be busy, preferring to spend the daytime hours transcribing and revising the material he had collected. Unlike some of his other billets, Mrs. McDermott and her family were primarily sheep farmers, the standard occupation for people in that area, and one of the few viable ways to make a living from the surrounding moorland. Mrs. McDermott rose very early and Ó hEochaidh comments on her loud calling at the crack of dawn, her incessant tending of the sheep and how it prevented him from sleeping (NFC 1289, 93; 100). At one point she entered his room with tea, followed by a sheep (NFC 1289, 94), something she thought completely unremarkable. Ó hEochaidh was there in the summer, a very busy time. Additionally, Mrs. McDermott, a widow, without the help of a husband, was obliged to perform both outside and domestic work. Essentially, she had to lead her sons in the work and perform tasks that would usually be left to the senior male. Her situation may be contrasted with the Mac a' Luain family (clann Eoghain Mhicheáil), where seven adult unmarried siblings, six brothers and a sister, lived together with their mother. Ó hEochaidh remarks in detail on the prosperity of this household noting that each of the brothers had his own dog (NFC 1289, 102-3).

It seems unsurprising then that Ó hEochaidh found Mrs. McDermott less engaged with the topics that interested him than others he encountered in the Croaghs. His descriptions reveal her as a woman deeply versed in oral lore, especially storytelling, like most of the 
people he met there. As he had done with Mrs. McGettigan, he wrote down her seanchas, including accounts about the local holy well, Tobar na nAingeal, and May Day belief (NFC 1289, 100-101). He remarked, however, that her lore was a little scattered, and that it was difficult to keep her on topic, as her mind was inclined to stray from the subject at hand (NFC 1289, 134). Clearly, Mrs. McDermott was preoccupied with managing a working farm and although her sons were growing fast, they still needed her guidance and support and could not yet be expected to take the lead fully themselves. She did not enjoy the leisure required to focus exclusively on the traditions that provided the materials for Ó hEochaidh's collecting. Contrasting Mrs. McDermott with Mrs. Friel, Mrs. McGettigan, Mrs. Duggan and Mrs. O'Donnell, it seems that these women enjoyed a less intensely busy life because their husbands were alive. They come across as more prosperous and less harried than their counterpart on the edge of the Bluestacks. We may also recall the bereaved mother as a further contrast, an incident that recalls a divergent value system that although it persisted, was changing. Through this contrast, we get a varied picture of women's lives in 1930s and 40s Ireland. Although materially less abundant than today's standards, some of the women Ó hEochaidh met enjoyed comfortable lives, while others had to work harder to get by. Those who were prosperous also worked hard, but the picture emerging from Ó hEochaidh's diaries reveals differing standards of living. Because of the level of material comfort enjoyed by some women, they could and did provide real assistance to Ó hEochaidh's work arising from their own interest in it.

Debora Kodish has shown that descriptions of the same recording sessions by male collectors and by their female informants differ markedly in their emphases, the men proud of their heroic discoveries of previously silent and passive women informants, the women stressing their family, their work and the other tasks they managed, visiting folklorists included (Kodish). In his diaries, we encounter women only through Ó hEochaidh's point of view. Although he clearly had set ideas about women as a category, however, they appear neither silent nor passive, as this paper has shown. Despite limitations, even an elderly, bedridden invalid ar chéill na bpáistí, "in her second childhood", emerges as an engaged acting being, as indeed do the others. Through their agency, these women frequently helped him in his work. By examining Seán Ó hEochaidh's field diaries, we get insights into life as lived in Donegal in the thirties and forties of the twentieth century. His vivid descriptions bring us into that world and, when we take a particular perspective, examining, for instance, the lives of women, we see how the prejudices, tensions, opportunities and limitations of the time affected the collecting project for the Irish Folklore Commission in disparate ways.

\section{Notes}

\footnotetext{
${ }^{1}$ Mrs. McCormack appears in both 1901 and 1911 censuses, where her first name is given as Bridget. Her age is given variously as 35 in 1901 and 53 in 1911, which would make her 71 or 79 in 1937 when Ó hEochaidh met her. 14 August 2017.

${ }^{2}$ The diaries are written in a pre-standardised orthography that also attempts to represent the peculiarities of Donegal Irish. For the purposes of this article, I have standardised the orthography while still allowing the dialectal features to remain. Irish texts are given first in all cases, followed by my own English translation.

3 Ó hEochaidh mentions "An Dúinín" as the townland, and this name is not found in the official placename register www.townlands.ie. I also failed to find a place of this name in Kilcar, in the placenames database www.logainm.ie. I identify An Dúinín as a subdivision of the townland of Doire Leathan, Derrylahan. Two Hegarty families appear in the 1911 census, only one of whom has a female named Annie (age 34) married to Condy (age 42). 14 August 2017.

http://www.census.nationalarchives.ie/pages/1911/Donegal/Kilcar/Derrylahan/486481/
} 


\section{Works Cited}

\section{Unpublished Sources}

National Folklore Collection (NFC) mss. 421, 584, 690, 727, 1107, 1108, 1109, 1289. Seán Ó hEochaidh's field diaries. Dublin: University College Dublin. All excerpts published by kind permission of the Delargy Centre for Irish Folklore.

Mac Aoidh, Seanán. Innéacs Ainmneacha Pearsanta agus Logainmneacha do Dhialanna Sheáin Uí Eochaidh. Unpublished Index of Personal Names and Placenames for Seán Ó hEochaidh's field diaries. 2015.

\section{Published Works}

Ainm.ie. "Seán Ó hEochaidh". 17 August 2017. http://www.ainm.ie/Bio.aspx?ID=1714.

Almqvist, Bo and Roibeard Ó Cathasaigh, eds. Ó Bhéal an Bhab: Cnuas-scéalta Bhab Feiritéar. Indreabhán: Cló Iar-Chonnachta, 2002.

Ardener, Edwin. "Belief and the Problem of Women", and "The Problem Revisited". Perceiving Women. Ed. Shirley Ardener. London: Malaby Press, 1975 (1968). 1-27.

Arensberg, Conrad M. and Solon T. Kimball. Family and Community in Ireland. Ennis: CLASP Press, 2001 (1940).

Bourke, Angela. "More in Anger than in Sorrow: Irish Women's Lament Poetry". Feminist Messages: Codings in Women's Folk Culture. Ed. Joan N. Radner. Urbana, University of Illinois Press, 1993. 160-182.

. "Performing Not Writing. The Reception of an Irish Woman's Lament". Dwelling in Possibility: Women Poets and Critics on Poetry. Ed. Yopie Prins and Maeera Shreiber. Cornell: Cornell University Press, 1993. 132-146.

. "The Virtual Reality of Irish Fairy Legend". Éire/Ireland 31 (1996): 1/2, 7-25.

. The Burning of Bridget Cleary. London: Pimlico, 1999.

Briody, Michael. The Irish Folklore Commission: History, Ideology, Methodology. Helsinki: Finnish Literature Society, 2007.

Carbery, Mary. The Farm by Lough Gur. Dublin: Lilliput Press, 2010 (1937).

Coughlan, Patricia. "An Léiriú ar Shaol na mBan i dTéacsanna Dírbheathaisnéise Pheig Sayers". Peig Sayers: Scéalaí 1873-1958. Ceiliúradh an Bhlascaoid 3. Ed. Máire Ní Chéilleachair. Baile Átha Cliath Coiscéim, 1999. 20-57.

. "Rereading Peig Sayers: Women's Autobiography, Social History and Narrative Art". Opening The Field: Irish Women, Texts and Contexts. Ed. Patricia Boyle Haberstroh and Christine St. Peter. Cork: Cork University Press, 2007. 58-73.

Danaher, Kevin. The Year in Ireland. Cork: Mercier Press, 1972.

Delargy, James, H. "The Gaelic Story-teller: with Some Notes on Gaelic Folk-tales [Sir John Rhŷs Memorial Lecture]". Proceedings of the British Academy 31 (1945): 177-221.

Donegal Times. "Bluestack Climb To Honour Airmen: Jim Gilchrist Revisits Crash Site. 14 May 2003. 17 March 2017. http://www.donegaltimes.com/2003/05_1/frontpage.html.

Ellis Davidson, Hilda. 2003. "Helpers and Adversaries in Fairy Tales". A Companion To The Fairytale. Ed. Hilda Ellis Davidson and Anna Chaudri. Cambridge: D.S. Brewer, 2003. 99-122.

Gramsci A. Selections from the Prison Notebooks. Edited and translated by Quintin Hoare and Geoffrey Nowell Smith. London: Lawrence and Wishart, 1971.

Kodish, Debora. "Absent Gender, Silent Encounter". The Journal of American Folklore 100 (1987): 398; 573-78. 
Lloyd, Albert L. and Haywood Magee. 1947. "The Irish Storyteller". The Picture Post. 15 March 1947. 23 August 2017. http://carrickonline.net/index.php/picture-post-march1947.

Louai, El Habib. "Retracing the Concept of the Subaltern from Gramsci to Spivak: Historical Developments and New Applications". African Journal of History and Culture. 4.1 (2012): 4-8. 17 August 2017. www.academicjournals.org/article/article1381909550_Louai.pdf.

Lysaght, Patricia. The Banshee: The Irish Supernatural Death Messenger. Dublin: O'Brien Press, 1986.

. "Visual Documentation of Irish Folk Tradition: Simon Coleman RHA in County Donegal, 3-19 December 1949." Atlantic Currents: Essays in Lore, Literature and Language: Essays in Honour of Séamas Ó Catháin. Eds. Bo Almqvist, Criostóir Mac Cárthaigh et al. Dublin: UCD Press, 2012. 98-112.

Ní Dhíoraí, Áine. Na Cruacha: Scéalta agus Seanchas. Dublin: An Clóchomhar, 1985.

Ní Dhuibhne, Eilís. "“The Old Woman as Hare': Structure and Meaning in an Irish Legend.” Folklore 104. 1/2 (1993): 77-85.

. "International Folktales". The Field Day Anthology of Irish Writing IV: Irish

Women's Writing and Traditions. Cork: Cork University Press in Association with Field Day, 2002. 1214-1218.

Ó Cadhla, Stiofán. "Dochtúirí, Sagart agus Bean". An tSlat Féithleoige: Na hEalaíona Dúchais 1800-2000. Indreabhán: Cló Iar-Chonnacht, 2011. 176-198.

Ó Catháin, Séamas. "Liam Mac Meanman.” Béaloideas 60 (1992-3): 290-295.

O'Connor, Anne. Child Murdress and Dead Child Traditions. Helsinki: Finnish Literature Society, 1991.

. The Blessed and the Damned: Sinful Women and Unbaptised Children in Irish Folklore. Oxford: Peter Lang, 2005.

Ó Crualaoich, Gearóid. The Book of the Cailleach: Stories of the Wise Woman Healer. Cork: Cork University Press, 2003.

Ó Giolláin, Diarmuid. Locating Irish Folklore: Identity, Modernity. Cork: Cork University Press, 2000.

—. 2005. An Dúchas agus an Domhan. Cork: Cork University Press, 2005.

O’ Sullivan, Seán. Irish Wake Amusements. Cork: Mercier, 1967.

Ortner, Sherry. "Is Female to Male as Nature is to Culture?" Feminist Studies 1.2 (1972): 531.

Ó Laoire, Lillis. "The Gaelic Undertow: Seán Ó hEochaidh's Field Trip to the Bluestacks in 1947”. This Landscape's Fierce Embrace: The Poetry of Francis Harvey. Ed. Donna

L. Potts. Newcastle: Cambridge Scholars' Press, 2013. 73-89.

. "Dialann Sheáin Uí Eochaidh". Donegal Annual 67 (2015): 109-115.

. "Humor and Gender in the Woman's Excuse as Told by Bab Feiritéar". American Journal of Irish Studies 13 (2016): 37-54.

Ó Seachnasaigh, Pól. 2012. Eagrán de na scéalta idirnáisiúnta ó na Cruacha Gorma a bhailigh Seán Ó hEochaidh do Choimisiún Béaloideasa Éireann i 1947 agus 1948. Unpublished Ph.D. dissertation. Maynooth: National University of Ireland. 17 August 2017. http://eprints.maynoothuniversity.ie/4505/.

Partridge (Bourke), Angela. “Wild Men and Wailing Women”. Éigse 18.1 (1980): 25-37.

- Caoineadh na dTrí Muire: Téama na Páise i bhFiliocht Bhéil na Gaeilge. Baile Átha Cliath: An Clóchomhar, 1982. 
Radner, Joan N. 1989. "The Woman Who Went to Hell: Coded Values in Irish Folk Narrative". Midwestern Folklore: Journal of the Hoosier Folklore Society 15.2 (1989): 109-118.

_ ed. Feminist Messages: Coding in Women's Folklore. Urbana: University of Illinois Press, 1993.

Spivak, Gayatri, Chakravorty. "Can The Subaltern Speak?" Marxism and the Interpretation of Culture. Eds. Cary Nelson and Lawrence Grossberg. Basingstoke: Macmillan Education, 1988. 271-313.

Taylor, Lawrence J. Occasions of Faith: An Anthropology of Irish Catholics. Philadelphia: University of Pennsylvania Press, 1995.

Uther, Hans-Jorg. The Types of International Folktales: A Classification and Bibliography, Based on the System of Antti Aarne and Stith Thompson. Helsinki: Suomalainen Tiedeakatemia, 2004.

Williams Sean and Lillis Ó Laoire. Bright Star of the West: Joe Heaney, Irish Song Man. New York: Oxford, 2015 (2011).

Received: 19 March 2017

Revised version accepted: 17 August 2017

Lillis Ó Laoire is Senior Lecturer in Irish Language \& Celtic Civilisation at NUI Galway, Ireland. He has published widely on Irish language song as well as essays on other folklore genres and on literature. He is editor of the journal Folk Life. He is working on preparing an edition of the field diaries of the Irish Folklore Commission's collector, Seán Ó hEochaidh, for publication.

lillis.olaoire@ nuigalway.ie 